\title{
Climate Change: Risky Business?
}

\author{
LARA E. LÁZARO TOUZA ${ }^{a}$, Michel S. ZOGHBY ${ }^{\text {b }}$ \\ a Colegio Universitario Cardenal Cisneros, c/ General Díaz Porlier, 58, 28006 Madrid, Spain. E- \\ mail: laralazaro@cu-cisneros.es \\ b Consultant. 68 rue de la Vierge, 01710 Thoiry, France. E-mail: mszoghby@gmail.com
}

\begin{abstract}
The recently released IPCC report states that climate change is unequivocal, unprecedented and anthropogenic in origin. Climate change is a three-pronged global externality with environmental, socio-economic and political consequences.. It may unleash 'catastrophic' losses in welfare if tipping points are crossed. Actions to avert catastrophic outcomes should arguably resemble insurance decisions rather than investment decisions. Early recommendations from the economics community on a climate policy ramp have been partially upended by stronger calls for action based, inter alia, on severe tail events. Efforts by the international community to respond to more urgent calls for action have so far failed to materialise. Future research on severe tail events, environmentally sound technologies and the establishment of more acceptable burden sharing agreements may improve the current grim prospects for effective and efficient climate action.
\end{abstract}

Keywords: Climate Change, Risks, Discount Rate, Tipping Points, Fat Tails, International Environmental Agreements.

\section{Cambio Climático: ¿Un negocio de alto riesgo?}

\section{RESUMEN}

El quinto informe del IPCC, recientemente publicado, afirma que el cambio climático es inequívoco, sin precedentes y antropogénico en origen. El cambio climático como externalidad global tiene consecuencias para el medio ambiente, la economía, la sociedad y la política. Dichas consecuencias podrían desencadenar pérdidas 'catastróficas' de bienestar si se sobrepasan determinados puntos críticos. Es posible argumentar que las acciones para evitar dichos resultados catastróficos deberían asemejarse a las decisiones relativas a la adquisición de seguros, que evitan las peores consecuencias de eventos catastróficos, más que a decisiones sobre inversiones. Las recomendaciones históricas de seguir una política de mitigación gradual han sido parcialmente desbancadas por llamadas más contundentes a la acción debido a la existencia de eventos extremos. Los esfuerzos de la comunidad internacional hasta la fecha han sido insuficientes para responder a las llamadas urgentes a la acción. La investigación de eventos extremos, el desarrollo de tecnologías respetuosas con el entorno y los acuerdos de reparto de carga aceptables para los distintos países, podrían favorecer una acción climática efectiva y eficiente.

Palabras Clave: Cambio climático, riesgos, tasa de descuento, puntos críticos, acuerdos ambientales internacionales.

Clasificación JEL: Q54, Q52, Q58

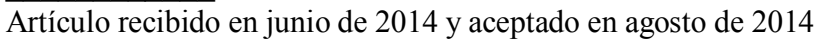

Artículo disponible en versión electrónica en la página www.revista-eea.net, ref. ə-32314 


\section{INTRODUCTION}

A stable climate is a global public good. Conversely, climate change is a global externality, the Goliath of externalities according to Nordhaus (2013). Climate change is defined in the IPCC's Fifth Assessement Report as 'a change in the state of the climate that can be identified (e.g., by using statistical tests) by changes in the mean and/or the variability of its properties, and that persists for an extended period, typically decades or longer' (IPCC, 2014a: 4). Climate change has defining features that make it a 'wicked problem': it has long term lag times between causes and effects; it is an unwanted by-product of virtually all economic activities and it affects all human and non-human species. Additionally, climate change can bring about catastrophic and irreversible effects (Jordan et al., 2010; Nordhaus, 2013; Stern, 2006; Weitzman, 2007).

The key drivers of GHG emissions are population growth, economic growth and energy intensity. Global population is expected to reach 9.6 billion by 2050 (UN, 2013) and global economic growth is expected to continue rising at rates similar to those of the past four decades (Ibid.). Energy intensity is falling globally, but not enough to offset GHG emission increases (Blodgett and Parker, 2010). It therefore follows that under current trends GHG emissions are expected to continue rising.

Considerations of the risks associated with rising GHG emissions have taken an increasingly important place within the Intergovernmental Panel on Climate Change (IPCC) process; a complex task as perceptions of risk differ across individuals and societies (Howes, 2005). However, no matter the perception of risk, improvements in climate modeling have considerably enhanced our understanding of climate change and its impacts, even though uncertainty on their magnitude and timing remain. The main message of AR5 is that warming of the planet is unequivocal, human beings are its primary cause and significant mitigation and adaptation measures will be required if we are to limit warming below $2^{\circ} \mathrm{C}$ above pre-industrial levels ${ }^{1}$.

That being said, there are also large uncertainties surrounding the economics of climate change (Tol, 2012), due in part to data gaps (especially for temperature increases above $3^{\circ} \mathrm{C}$ ), model limitations and omissions. The fundamental debates regarding the economics of climate change have focused on the 'discounting debate' until the responses to the Stern Review unleashed a broader framing of the issue by the economics community. Issues of tipping points, fat

\footnotetext{
${ }^{1}$ According to AR4, experts have been analysing levels of tolerable climate change risk since the 80 's. Said experts determined that average global temperature increases above $2^{\circ} \mathrm{C}$ compared to pre-industrial levels would entail rapid increases in 'risks of grave damage to ecosystems, and of non-linear responses'. http://www.ipcc.ch/publications_and_data/ar4/wg3/en/ch1s1-2-2.html
} 
tails and catastrophic events have recently escalated positions in the climate change agenda for economists.

As regards the management of climate change, markets will fail to internalise the consequences of climate change without government intervention. The global nature of the problem in the absence of a 'World Environmental Organisation' further complicates climate action. Past international climate agreements have fallen short of the efforts needed to avert dangerous interference with the climate system. The future of a global climate architecture is still unknown. Hence, the prospects for effective international climate action are grim.

The present article will analyse climate change as a three-pronged issue, scientific, economic and political. The analysis is based on a review of recent scientific, economic and governance literature. Section two will briefly discuss the basic features of climate related risks. Section three will present the key scientific findings analysed in the IPCC's Fifth Assessment Report (henceforth AR5) as regards climate impacts. The on-going debates regarding the economics of climate change will be discussed in section four. Section five will reflect on the governance of climate change. Section six will conclude.

\section{CLIMATE CHANGE: RISKY BUSINESS?}

Traditionally, risks have been defined as the probability of harm taking place and the severity of its impacts ${ }^{2}$ (Baldwin et al., 2012; IPCC, 2014a). More recently, risks have also been defined as a perceived hazard (Howes, 2005) occurring in social settings where more or less resilience to these can be observed. Hazards in turn can be understood as 'a situation or intrinsic property with the potential to cause a problem' (Singley, 2004: 14). Additionally, AR5's Working Group II (henceforth WGII) understands risks as arising from the interaction of 'vulnerability, exposure and hazards".

The significant focus on risk, which is new in AR5, aims to provide stakeholders with the necessary framework for better decision-making in responding to climate change, a rather complex task as individuals and societies' perception of risk differ based on values and objectives (IPCC, 2014a). WGII's contribution to AR5, nevertheless, strives to assess risks across contexts and through time in order to provide decisions-makers with the required tools to evaluate the

\footnotetext{
${ }^{2}$ WGII uses the term impacts 'primarily to refer to the effects on natural and human systems of extreme weather and climate events and of climate change' (IPCC, 2014a: 4).

${ }^{36}$ Hazard: The potential occurrence of a natural or human-induced physical event or trend or physical impacts. Exposure: The presence of people, ecosystems and assets in places and settings that could be adversely affected. Vulnerability: The propensity or predisposition to be adversely affected encompassing elements such as sensitivity to harm and lack of capacity to adapt' (IPCC, 2014a: 4).
} 
point at which climate change becomes a dangerous risk. Natural and anthropogenic drivers of climate risks as well as socioeconomic processes that influence said risks are depicted in Figure 1 below.

Figure 1

Risks in the 5AR

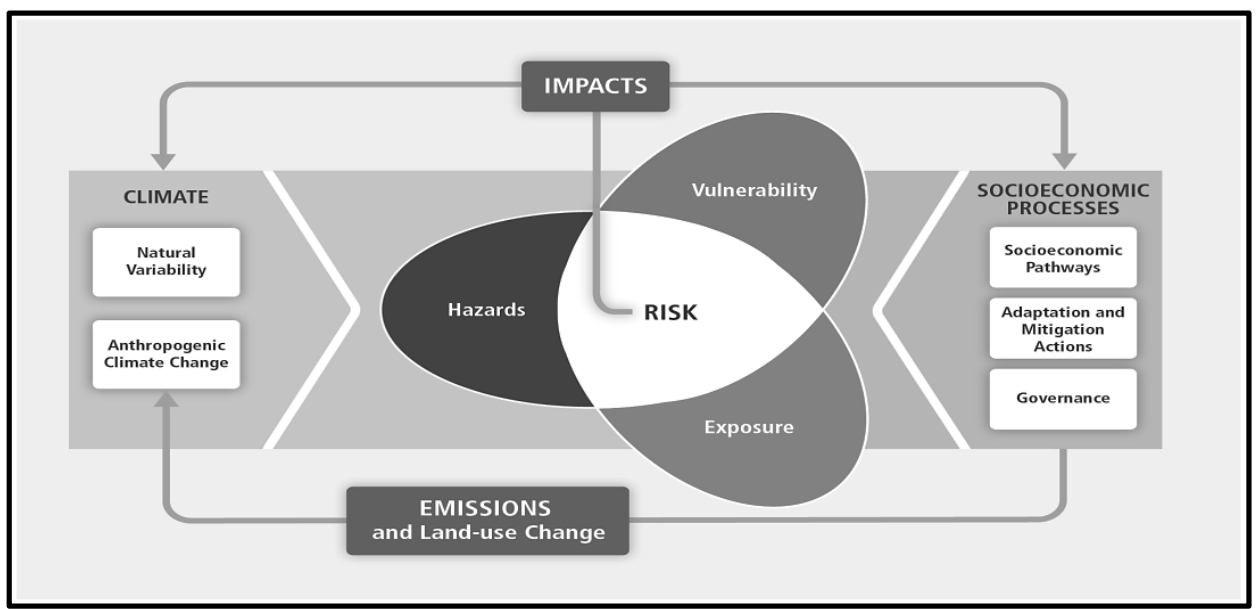

Source: IPCC (2014a: 35).

The challenge to 'understanding future vulnerability, exposure, and response capacity of interlinked human and natural systems' is mainly due to the significant number of 'interacting social, economic, and cultural factors' (IPCC, 2014a: 11). These factors have been more comprehensively considered in AR5 than in previous IPCC Assessment Reports although other IPCC work on managing the risks of extreme events (IPCC, 2012) signalled the new focus on risk. Other institutions such as the US National Research Council have also recently focused on abrupt climate impacts that lead to rapid changes to environmental or human systems, which can occur in years or decades (NRC, 2013).

In developing an approach for assessing key risks across sectors and regions, WGII built on the five reasons for concern (RFCs) first proposed in the IPCC Third Assessment Report (2001). RFCs highlight our understanding of impacts and the limits of adaptation while providing a point of departure in assessing the effects of human-induced warming on societies, economies and ecosystems. They and their associated risks are highlighted in Table 1. 
Table 1

Reasons for concern (RFC)

\begin{tabular}{|l|l|}
\hline \multicolumn{1}{|c|}{ Reasons for Concern (RFCs) } & \multicolumn{1}{|c|}{ Risk } \\
\hline Unique and threatened systems & $\begin{array}{l}\text { Due to their limited adaptive capacity, many species and systems will face } \\
\text { very high risks with } 2^{\circ} \mathrm{C}^{4} \text { additional warming }\end{array}$ \\
\hline Extreme weather events & $\begin{array}{l}\text { Risks resulting from extreme events are moderate at recent temperatures, } \\
\text { high at } 1^{\circ} \mathrm{C} \text { and increase further at higher temperatures }\end{array}$ \\
\hline Distribution of impacts & $\begin{array}{l}\text { Disadvantaged communities are at greater risk, with these vulnerabilities } \\
\text { becoming high above } 2^{\circ} \mathrm{C} \text { additional warming }\end{array}$ \\
\hline Global aggregate impacts & $\begin{array}{l}\text { Moderate between } 1-2^{\circ} \mathrm{C} \text {. The loss of biodiversity and associated ecosystem } \\
\text { services yield high risks near } 3^{\circ} \mathrm{C} \text { additional warming. Aggregate economic } \\
\text { costs grow with increased temperature }\end{array}$ \\
\hline Large-scale singular events & $\begin{array}{l}\text { Additional warming may lead to abrupt and irreversible changes. The risks of } \\
\text { reaching these tipping points }{ }^{5} \text { remain moderate between } 0-1^{\circ} \mathrm{C} \text { additional } \\
\text { warming, increase significantly at } 1-2^{\circ} \mathrm{C} \text { and are high above } 3^{\circ} \mathrm{C}\end{array}$ \\
\hline
\end{tabular}

Source: Adapted from (IPCC, 2014a,d).

With the above definitions and characterisations of risks in mind, we now turn our attention to the science of climate change.

\section{THE PHYSICAL SCIENCE BASIS}

Projecting the impacts of climate change for the next 100 years on humans and the planet is a daunting task. Much of our ability to do so rests on our capacity to observe past and present conditions as well as develop scenarios characterizing various possible future pathways, the risks associated with their impacts as well as the implications of our attempts at mitigating and adapting to climate change (IPCC, 2014d). The climate projections used in the 2007 Fourth Assessment Report (AR4) were based on 4 scenarios families from the 2000 Special Report on Emissions Scenarios (SRES) (IPCC, 2000a), which first defined socio-economic scenarios that lead to various alternate GHG emission scenarios. In contrast, AR5 climate projections are based on the 4 scenarios in Table 2 called Representative Concentration Pathways (RCPs), which define GHG concentrations to be shared by all climate change modelling communities.

Based on the RCPs, AR5 working Group I's (henceforth, WGI) overall assessment of climate change over the last several decades is that 'warming of the climate system is unequivocal, and since the 1950s, many of the observed changes are unprecedented over decades to millennia' (IPCC, 2014c: 4). WGI also confirms that human beings have been the primary cause of climate change, finding that it is extremely likely ${ }^{6}$ (up from very likely in AR4) that over

${ }^{4}$ All RCF-related temperatures in this table are given as global average temperature change relative to $1986-2005$.

${ }^{5}$ A tipping point according to Lenton et al. (2008: 1786) is defined as a 'critical threshold at which a tiny perturbation can qualitatively alter the state or development of a system'.

${ }^{6}$ In the AR5 Summary for Policymakers, 'the following terms have been used to indicate the assessed likelihood of an outcome or a result: virtually certain $99-100 \%$ probability, very likely 
$50 \%$ of the global average temperature increase since the mid- $20^{\text {th }}$ century was man-made (IPCC, 2014c); the total anthropogenic radiative forcing estimated for 2011 being 43\% higher than AR4's figure for 2005 (IPCC, 2014c). In terms of uncertainty, compared to AR4, better observations and enhanced modelling in AR5 have allowed to pinpoint with greater accuracy the man-made contribution to changes in various climate mechanisms (IPCC, 2014c).

Table 2

The four RCPs

\begin{tabular}{|l|l|}
\hline \multicolumn{1}{|c|}{ Name } & \multicolumn{1}{c|}{ Description } \\
\hline RCP 8.5 & Rising radiative forcing pathway with $\sim 1370 \mathrm{ppm}$ CO2e leading to $8.5 \mathrm{~W} / \mathrm{m} 2$ in 2100 \\
\hline RCP 6 & Stabilization without overshoot pathway with $\sim 850 \mathrm{ppm}$ CO2e leading to $6 \mathrm{~W} / \mathrm{m} 2$ at stabilization after 2100 \\
\hline RCP 4.5 & Stabilization without overshoot pathway with $\sim 650 \mathrm{ppm} \mathrm{CO2e} \mathrm{leading} \mathrm{to} 4.5 \mathrm{~W} / \mathrm{m} 2$ at stabilization after 2100 \\
\hline RCP 2.6 & Peak in radiative forcing with $\sim 490 \mathrm{ppm} \mathrm{CO2e} \mathrm{leading} \mathrm{to} \sim 3 \mathrm{~W} / \mathrm{m} 2$ before 2100 and decline \\
\hline
\end{tabular}

Source: Adapted from http://sedac.ipcc-data.org/ddc/ar5_scenario_process/RCPs.html and Jubb (Undated).

With these enhanced modelling capabilities and overall improved assessment, AR5 retains AR4's target of restricting anthropogenic warming to less than $2{ }^{\circ} \mathrm{C}$, requiring man-made cumulative $\mathrm{CO}_{2}$ emissions to remain between 0 and about $1210 \mathrm{GtC}^{7}$ if $2^{\circ} \mathrm{C}$ is to be achieved with a probability greater than $50 \%$; reminding the reader that an amount of approximately $515 \mathrm{GtC}$ was already emitted by 2011 with a globally averaged temperature rise of $0.85^{\circ} \mathrm{C}$ $\left(0.76^{\circ} \mathrm{C}\right.$ for AR4) since pre-industrial levels. Looking forward towards the end of the $21^{\text {st }}$ century, WGI projects the range of mean cumulative $\mathrm{CO}_{2}$ emissions and global mean surface temperature range for all scenarios to be between 270 and $1685 \mathrm{GtC}$ and 1 and $3.7^{\circ} \mathrm{C}$ respectively (IPCC, 2014c).

Today, all species live in a world where greenhouse gases concentrations have risen to levels not witnessed for at least 800,000 years. $\mathrm{CO}_{2}$ concentrations stood at $391 \mathrm{ppm}^{8}$ in 2011, an increase of $40 \%$ since pre-industrial times. The effects of $\mathrm{CO}_{2}$ emissions are a function of climate sensitivity to $\mathrm{CO}_{2}{ }^{9}$ and WGI

$90-100 \%$, likely $66-100 \%$, about as likely as not $33-66 \%$, unlikely $0-33 \%$, very unlikely $0-10 \%$, exceptionally unlikely $0-1 \%$. Additional terms (extremely likely: $95-100 \%$, more likely than not $>50-100 \%$, and extremely unlikely $0-5 \%$ ) may also be used when appropriate. Assessed likelihood is typeset in italics' (IPCC, 2014c: 4).

7 ' 1 Gigatonne of carbon $=1 \mathrm{GtC}=1015$ grams of carbon. This corresponds to $3.667 \mathrm{GtCO}$ ' (IPCC, 2014c: 12).

8 'ppm (parts per million): is the ratio of the number of gas molecules to the total number of molecules of dry air. For example, 300 ppm means 300 molecules of a gas per million molecules of dry air' (IPCC, 2014c: 11).

${ }^{9}$ Equilibrium climate sensitivity is defined 'as the change in global mean surface temperature at equilibrium that is caused by a doubling of the atmospheric $\mathrm{CO}_{2}$ concentration' (IPCC, 2014c: 16). 
slightly broadens the equilibrium climate sensitivity range from $2{ }^{\circ} \mathrm{C}$ to $4.5^{\circ} \mathrm{C}$ in AR4 to $1.5^{\circ} \mathrm{C}$ to $4.5^{\circ} \mathrm{C}$. Looking forward, WGI finds that climate change will influence carbon cycle processes, increasing the rate at which $\mathrm{CO}_{2}$ is rising in the atmosphere. Also, due to the fact that most aspects of climate change will continue for centuries no matter the level of GHG emissions, WGI warns that the impacts of anthropogenic radiative forcing will affect humans today and our children for many centuries to come (IPCC, 2014c).

While climate change is unambiguous and is principally influenced by human emissions, its consequences are regionally irregular in addition to showing 'interannual-to-decadal variability' (IPCC, 2014c: 20). This variability has clearly been demonstrated by the reduced rate of surface warming observed over the past 15 years, which WGI attributes with medium confidence in roughly equal measure to radiative forcing and natural internal variability (Ibid.). However, this decadal reduced rate of surface warming does not contradict observations or long-term climate trends. In fact, WGI demonstrates that the findings published in AR4, in both patterns and magnitude, are by and large being confirmed by AR5's findings. We now turn our attention in Table 3 below to some of the other specific findings of WGI:

Table 3

Other significant AR5 findings

\begin{tabular}{|c|l|l|}
\hline Observations & \multicolumn{1}{|c|}{ Present } & \multicolumn{1}{|c|}{ Future } \\
\hline $\begin{array}{c}\text { Extreme Weather } \\
\text { Events (EWE) }\end{array}$ & $\begin{array}{l}\text { Globally, cold days/nights decreased and } \\
\text { warm day/nights increased; heat waves } \\
\text { frequency have increased; precipitations have } \\
\text { been heavier and more frequent in more } \\
\text { regions }\end{array}$ & $\begin{array}{l}\text { Heat waves will increase in frequency while cold winter } \\
\text { extremes will occasionally occur }\end{array}$ \\
\hline Oceans & $\begin{array}{l}\text { Ocean warming, in the upper } 75 \mathrm{~m} \text {, increased } \\
\text { by } 0.11^{\circ} \mathrm{C} \text { per decade in the last } 35 \text { years; } \\
\text { Ocean surface water pH has decreased by 0.1 } \\
\text { since pre-industrial times }\end{array}$ & $\begin{array}{l}\text { Ocean circulation will be affected by warming as deep } \\
\text { ocean temperature increases; however, it is very } \\
\text { unlikely that major circulation systems will experience } \\
\text { abrupt changes or collapse in the } 21^{\text {st }} \text { century }\end{array}$ \\
\hline Sea-Level Rise & $\begin{array}{l}\text { During the last century, seal level has risen } \\
0.19 \mathrm{~m} \text { due primarily to glacier melting and } \\
\text { thermal expansion of oceans }\end{array}$ & $\begin{array}{l}\text { Projected sea level rise by } 2100 \text { is expected not to be } \\
\text { uniform and to range from } 0.4 \mathrm{~m} \text { to 0.63 } \mathrm{m} \text {; a majority of } \\
\text { coastlines are expected to be affected; in the event the } \\
\text { Greenland ice sheet was to melt, sea level rise could } \\
\text { reach } 7 \text { m; sea level rise is expected to continue well } \\
\text { beyond 2100 }\end{array}$ \\
\hline Cryosphere & $\begin{array}{l}\text { Greenland and Antarctic ice sheets have lost } \\
\text { mass; glaciers have been shrinking; Arctic see } \\
\text { ice is thinning; permafrost has been warming } \\
\text { in most regions }\end{array}$ & $\begin{array}{l}\text { The Artic is expected to warm faster than other } \\
\text { regions, with an associated thinning of sea ice cover; } \\
\text { glaciers will continue to shrink and surface permafrost } \\
\text { at high latitudes will continue to warm }\end{array}$ \\
\hline
\end{tabular}

Source: Adapted from (IPCC, 2014c).

Finally, WGI mentions that while man-made climate change is mostly irreversible, geoengineering methods such as Solar Radiation Management (SRM) and Carbon Dioxide Removal (CDR) have been proposed to remove $\mathrm{CO}_{2}$ from the atmosphere. However, because of the limited evidence available on CDR and SRM methods it isn't yet feasible to quantitatively assess their viability and effectiveness in a comprehensive way. That being said, WGI emphasises that 
these methods do 'carry side effects and long-term consequences on a global scale' (IPCC, 2014c: 29).

This section has presented some of the most salient issues regarding the physical science of climate change. However, as Nordhaus (2013: 50) states, 'climate change is no longer just geophysics and ecology, it has become economics and politics'. It is to these last two issues that we now turn.

\section{THE ECONOMICS OF CLIMATE CHANGE}

The essence of the problem posed by climate change for economics is arguably that the discipline has been 'stretched' beyond the marginal realm and beyond markets' lifetime. This stretching is a consequence of the long term residence time of GHG in the atmosphere as well as of the existence of nonnegligible probabilities of 'disastrous collapse of planetary welfare' (Weitzman, 2009: 1) that arise as a consequence of the impacts of global stock pollutants (GHGs). Said pollutants are global public bads, non-rival, non-excludable and, in the absence of policy intervention, under-priced and hence produced in inefficient amounts.

The contribution of economics to the analysis of climate change reviewed below will focus on a brief reflection on the key debates that took place after the publication of The Stern Review on the Economics of Climate Change and on advancements since the publication of the Review both at a macro and micro levels.

\subsection{Early analyses and debates}

Development and climate conditions have been of interest to scholars since at least the $\mathrm{XIV}^{\text {th }}$ century (Dell et al., 2011). Large uncertainties and heated debates remain however regarding the economics of climate change. Economic modelling of the costs associated with ensuring a stable climate requires decision-makers to make a number of value-based assumptions in a very uncertain climate and economic future.

Although a review of different ethical approaches to the economics of climate change are outside the scope of this paper their utmost relevance should be acknowledged when analysing actions that will have implications for those who are less well off, future generations and the environment (Dietz, Hepburn and Stern, 2008; Stern, 2013a; Stern, 2013b). That said, it is important to note that economic analysis of climate change, especially when it implies undertaking cost benefit analysis (CBA), assumes a utilitarian welfare economics ethical approach according to which outcomes are evaluated based to the consequences they produce. These consequences can in turn be measured in terms of (human) consumption of market and non-market goods, compared and added up through the use of a social welfare function (Hope, 2006). Broader ethical approaches, 
such as the pluralistic ethical approach, are however worth exploring as they can provide an additional moral compass in accounting for issues related to needs, rights and virtuous decisions, key in tackling multifaceted problems such as climate change (Dietz, 2011a; Stern, 2013a).

In order to provide a stable climate contemporary research prior to the publication of the Stern Review focused on undertaking relatively straightforward cost benefit analysis of GHG emission reductions (Nordhaus, 2012). These analyses overall supported a climate policy ramp whereby moderate emission reductions were called for in the short run. Reductions would rise over time as consequences of climate change worsened (Nordhaus, 2012; Weitzman, 2007). Implicitly, this approach assumed no critical natural capital would be destroyed, no tipping points would be crossed and therefore no urgent actions were needed. The release of the landmark report commissioned by the UK government titled the Stern Review on the economics of climate change proposed a radically different approach. The Review recommended deep emission reductions in the short run, arguing that the costs of such cuts were lower than the benefits from mitigation (i.e. avoided damages).

Climate change costs and benefits are generally analysed using Integrated Assessment Models (IAMs) ${ }^{10}$. Estimates of the total economic costs of climate change in terms of global output (variations in world GDP measured in \% terms) for different temperature increases, as well as estimates of the social cost of carbon (SCC) ${ }^{11}$, are provided by IAMs. Among the IAMs in use we have those that account only for well-known market impacts, those that also include non-market impacts and more comprehensive models that additionally include the risk of abrupt changes to the climate system. None of these models include 'socially contingent' outcomes (Stern, 2007; Dietz et al., 2007) such as social unrest or conflict and migration (DoD, 2010, Stern, 2013a). Equally relevant as regards cost estimates, it is rare that these models explicitly include interactions of impacts (Dietz et al., 2007).

Insofar as climate change models fail to fully reflect the costs to all human and non-human systems, fail to fully account for risks of large scale climate disruptions and do not account for socially contingent outcomes, they will systematically bias the cost of climate change, underestimating true costs (IPCC, 2014a). The main models in use are briefly presented in Box 1 below.

${ }^{10}$ IAMs have been defined as 'multiequation computerized models linking aggregate economic growth with simple climate dynamics to analyse the economic impacts of global warming' (Weitzman, 2009: 15-16).

${ }^{11}$ The SCC provides information on the impacts of emitting one tonne of carbon along different emission pathways. 


\section{Box1}

Main IAMs in use

- $\quad$ Mendelsohn et al. (1998) only include a small subset of market impacts (both positive and negative). They do not use equity weightings. Their estimates of the total cost of climate change ranges from no impact to a slight growth in GDP due to climate change.

- $\quad$ Tol's FUND model includes a wide set of impacts but fails to account for abrupt climate change. The model provides estimates with and without utility-based equity weighting. Estimates of the total economic cost of climate change are positive (i.e. society incurs economic losses) for temperature increases beyond $2^{\circ} \mathrm{C}$, but are restricted to approximately $2 \%$ of world GDP even for temperature increases of $6^{\circ} \mathrm{C}$

- $\quad$ Nordhaus and Boyer's DICE model includes market and non-market impacts as well as impacts derived from abrupt climate change. They also provide estimates with and without population-based equity weighting as well as information regarding willingness to pay to avert sudden large-scale climatic change. Estimates of the total cost of climate change are the largest for global average temperature increases above $2^{\circ} \mathrm{C}$ in Figure 4 below.

- The PAGE 2002 model, used in the Stern Review (2007), was built by Cambridge economist Chris Hope. This model analyses the total economic costs of warming using a stochastic approach that includes Monte-Carlo analysis to estimate probabilities and is calibrated to account for uncertainties regarding scientific and economic issues. It includes market and nonmarket impacts as well as the risk of large-scale discontinuities. The total costs of climate impacts are significant above $2^{\circ} \mathrm{C}$ warming, but are smaller than those estimated by Nordhaus and Boyer (2000).

Source: Adapted from Dietz et al., (2007) and IPCC, (2007b).

Estimates of impacts on GDP for different temperature increases are provided in Figure 2.

Figure 2

Undiscounted costs of climate change as a function of warming compared with a no climate change world

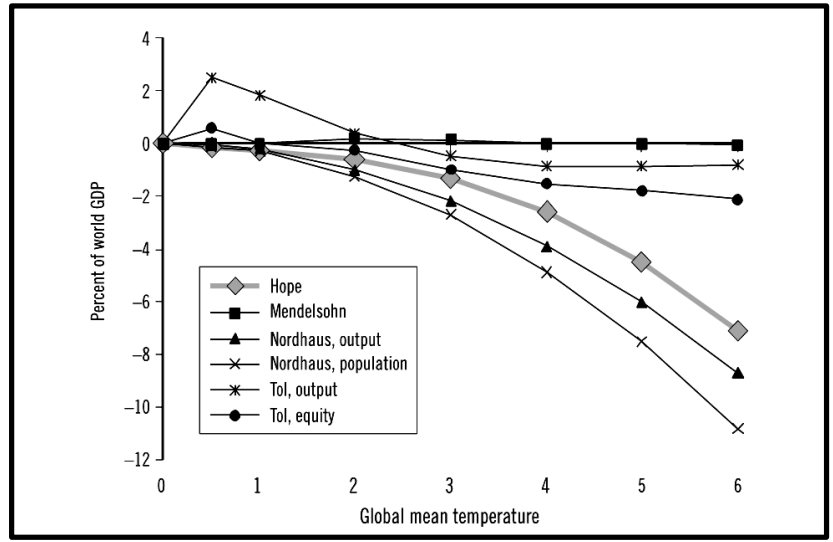

Source: Dietz et al. (2007: 132).

Overall we can see from Figure 2 that from an economic perspective, and bearing in mind the model limitations discussed above, increases in temperature up to $2^{\circ} \mathrm{C}$ will have a positive or a slightly negative effect on global economic growth. Beyond two degrees things tend to get significantly worse, loosing up to around $10 \%$ of global GDP.

The Stern Review further estimates that losses in GDP could range between $5 \%$ and $20 \%$ depending on the impacts included. The reasons for Stern's figure to be higher than previous estimates according to Hope (2006) are that the Stern 
Review included: more updated literature; all the reasons for concern (RFCs) described in section 3 above and it used lower rates of pure time preference.

More recent estimates of the global economic impact of climate change presented by AR5 are also limited in their coverage; few studies are available for average temperature increases above $3^{\circ} \mathrm{C}$ and existing studies do not provide all-encompassing analyses of the economic impacts of climate change. Figure 3 below shows the existing estimates of the total impacts of climate change for different temperatures.

Figure 3

Total impact of climate change (\%GDP) for different temperatures $\left({ }^{\circ} \mathrm{C}\right)$

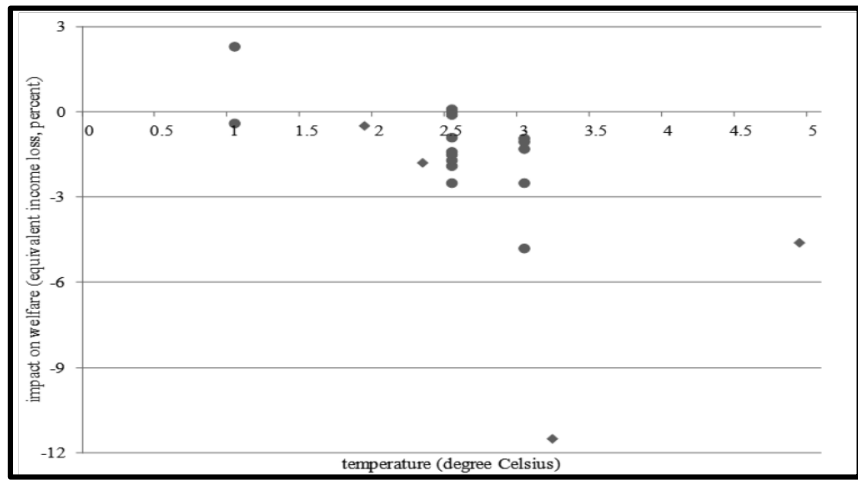

Source: (IPCC, 2014a: 84).

Given the information set out above on the costs of climate change as a function of warming (Figures 2 and 3), the next question that would logically follow is, what are the costs to the overall economy of stabilising GHG emissions at a level that would give us a likely chance of limiting climate change to $2^{\circ} \mathrm{C}$ above pre-industrial levels?

Various methods can be used in estimating these costs (Stern, 2007). Overall the resource cost method used in the Stern review estimated that cutting GHG emissions to three quarters of 2007 levels by mid century would entail a cost of $1 \%$ of 2050 world GDP on average (with estimates ranging between $-1 \%$, i.e. net benefit of stabilisation, to $3.5 \%$, i.e. net costs of stabilisation). Findings from other models analysed in the Review are consistent with the average cost of $1 \%$ of global GDP although the range of results is larger, $+/-3 \%$ of global GDP (see chapter 10 of the Stern Review for further details).

So, according to the Stern Review unabated climate change could imply losses to global GDP of 5\% to $20 \%$ and the costs of stabilising GHG emissions to have a likely chance of staying within the $2^{\circ} \mathrm{C}$ mark would amount to $1 \%$ of global GDP. A priori, a logical recommendation would be to engage in deep emission reductions. The 'catch', according to Hope (2006), of Stern's high 
benefit-cost ratio lies in the asymmetry of impacts. While costs of mitigation are to be borne by developed countries in the short run, benefits will accrue in the long run to a range of countries. This asymmetry, among other factors, makes global climate agreements elusive.

The AR4 report released just after the Stern Review presented the consensus peer reviewed range of GDP variation estimates for different GHG stabilisation levels, see Table 4 below.

Table 4

Estimated changes in global GDP for different stabilisation levels

\begin{tabular}{|c|c|c|c|c|c|c|}
\hline $\begin{array}{c}\text { Stabilisation } \\
\text { Levels } \\
\left(\mathbf{p p m} \mathbf{C O}_{2} \mathbf{e}\right)\end{array}$ & \multicolumn{2}{|c|}{ Mean GDP reduction (\%) } & \multicolumn{2}{c|}{ Range of GDP reduction (\%) } & \multicolumn{2}{c|}{$\begin{array}{c}\text { Reduction of average annual } \\
\text { GDP growth rates (\%) }\end{array}$} \\
\hline & 2030 & 2050 & 2030 & 2050 & 2030 & 2050 \\
\hline $445-535$ & \multicolumn{2}{|c|}{ Not available } & $<3$ & $<5.5$ & $<0.12$ & $<0.12$ \\
\hline $535-590$ & 0.6 & 1.3 & 0.2 to 2.5 & $\begin{array}{c}\text { Slightly } \\
\text { negative to } 4\end{array}$ & $<0.1$ & $<0.1$ \\
\hline $590-710$ & 0.2 & 0.5 & -0.6 to 1.2 & -1 to 2 & $<0.06$ & $<0.05$ \\
\hline
\end{tabular}

Source: (IPCC, 2007a: 69).

According to Table 4 above, for different GHG stabilisation pathways, the economic impacts may range from 1\% gains in GDP to losses of less than 5.5\% in the two time horizons studied, 2030 and 2050. Mean GDP reductions at 535$590 \mathrm{ppm}$ of $\mathrm{CO}_{2} \mathrm{e}$ are roughly consistent with findings from the Stern Review.

More recent analysis undertaken in the context of the EU RECIPE project analysing the costs of stabilising GHG emissions at approximately 530 to 550 ppm $\mathrm{CO}_{2} \mathrm{e}$ estimate lower global consumption amounting to $1.4 \%$ over this century. Should climate policy, or the deployment of low carbon technologies be delayed, costs could be significantly higher (Luderer et al., 2012).

On a micro scale, IAMs also provide information on the social cost of carbon. The SCC measures 'the present discounted value of the additional social costs (or the marginal social damage) that an extra tonne of carbon released now would impose on the current and future society' (Hope, 2006: 10) ${ }^{12}$. Table 5 below summarises some of the key figures of the social cost of carbon provided in the Stern Review. As acknowledged by Stern, the features of the Review that drive up Stern's SCC, as well as aggregate impacts on GDP (see above) compared to previous studies include: more weight given to the possibility of severe climate change as well as to non-market impacts; the use of a low rate of pure time preference; the equity weighting used; attention paid to work on uncer-

${ }^{12}$ Hope (2006: 14) explains that in order to calculate the SCC the PAGE model for example finds 'the difference in the discounted economic cost of climate change impacts between two emission scenarios that are identical except for the emission of an extra one billion tonnes of carbon as $\mathrm{CO}_{2}$ in 2001 for one of the scenarios. The difference in impacts is divided by one billion to obtain the SCC'. 
tainty about climate sensitivity and the inclusion of work regarding feedbacks and risks of extreme weather events (EWE) (Stern, 2007).

Table 5

The Stern Review's SCC under BAU and under stabilisation pathways

\begin{tabular}{|l|l|l|}
\hline \multicolumn{1}{|c|}{ Reference } & \multicolumn{1}{c|}{ SCC - BAU } & \multicolumn{1}{c|}{ SCC- Stabilisation targets } \\
\hline Nordhaus and Boyer $(2000)$ & Not available & $\$ 2.48 / \mathrm{tCO}_{2}$ in 2001-2010 (year 2000 prices) \\
\hline US CCSP review & Not available & $\$ 2 / \mathrm{tCO}_{2}-\$ 20 / \mathrm{tCO}_{2}$ in 2020 \\
\hline Edenhofer et al. in Stern & Not available & $\$ 0 / \mathrm{tCO}_{2}-\$ 12 / \mathrm{tCO}_{2}$ in 2010 (year 2000 prices) \\
\hline Stern & $\$ 85 / \mathrm{tCO}_{2}(2000$ prices; $\$ 312 / \mathrm{tC})$ & $\$ 30 / \mathrm{tCO}_{2}\left(550 \mathrm{ppm} \mathrm{CO}_{2} \mathrm{e}\right)-\$ 25 / \mathrm{tCO}_{2}\left(450 \mathrm{ppm} \mathrm{CO}_{2} \mathrm{e}\right)$ \\
\hline
\end{tabular}

Source: Stern (2007).

More updated estimates of the social cost of carbon are provided by AR5 (Table 6).

Table 6

Social cost of carbon. Estimates post AR4

\begin{tabular}{|c|c|c|}
\hline Pure rate of time preference & Average $(\$ / \mathbf{t C})$ & Standard Deviation $(\$ / \mathbf{t C})$ \\
\hline $0 \%$ & 270 & 233 \\
\hline $1 \%$ & 181 & 260 \\
\hline $3 \%$ & 33 & 29 \\
\hline
\end{tabular}

Source: (IPCC, 2014a: 80).

The estimates of the SCC presented in the Stern Review and in AR5 are wide raging. According to the latter as well as to analysis by Hope (2006), Nordhaus (2007) or Weitzman (2007) among others, the discrepancies in the SCC arise largely due to differences in discount rates used. Hope (2006) ads that assumptions regarding future economic development or ranges and likelihood of damages for different temperature increases, also determine differences in the estimated impacts of emitting an extra tonne of carbon. The AR5 also mentions equity weighting and risk aversion as factors that explain the existence of wide ranging estimates of the SCC.

Among the different factors explaining the wide-ranging estimates of GDP impacts, and equally divergent values for the SCC, it was arguably the discount rate variable that attracted the largest share of (academic) attention. Nordhaus (2007) for example disagreed with the use of the near zero rate of pure time preference used in the Stern Review that implies that future generations are accounted for just as present generations are. According to Nordhaus the results from the Stern review are inconsistent with the markets' return on capital. The so-called Stern review 'damage puzzle' is solved in Nordhaus' view when large future damages are 'magnified' by a very low rate of pure time preference (Nordhaus, 2007). The defence however of the high value of the SCC presented by Stern, according to Hope (2006), rests on either arguing that discrimination 
by date of birth (i.e. having high rates of pure time preference) is not valid or because current mitigation can be seen as an insurance premium against future catastrophe.

In another prominent response to the Stern Review, Weitzman (2007) acknowledges that Stern's conclusions are highly dependent on the (low) discount rate used that is based on unconventional assumptions that are contrary to mainstream economic analysis and to observed economic behaviour. He nevertheless states that a comprehensive account of the full uncertainty regarding the discount rate may result in Stern's discount rate being acceptable. Additionally, he states that the very long time horizons in which GHG emissions impact the global climate call for using 'low' discount rates. Weitzman nevertheless contends that prompt and decisive action called for by the Stern Review would result from the possibility of severe tail events rather than from the use of a low discount rate. This insight, among other factors to which we now turn, led to a new focus on the economics of climate change.

\subsection{Recent focus: severe fat tails}

Since 2007, the economic analysis of smooth changes to the climate system and policy ramp recommendations evolved to include the analysis of more severe and abrupt consequences of climate change and recommendations of prompt and decisive action ${ }^{13}$. When severe events that are outside our expectations occur they are known as 'tail events' (Nordhaus, 2012). The relative shift in focus, from the discounting sparring match to the 'tails' pseudo consensus, was arguably facilitated by the release of The Stern Review on the Economics of Climate Change. The shift was also brought about by the greater emphasis in the literature regarding abrupt climate change and tipping points. Finally, the work of Weitzman $(2007,2009)$ and Nordhaus (2012) on severe tail events has also helped push the boundaries of early economic analysis of climate change.

In fact, Weiztman's (2007) review of the Stern Review could be seen as a wake up call regarding the relevance of severe tail events in the economics of climate change. Wietzman highlights that implications of low probability high impact events have not been sufficiently addressed in CBAs undertaken in the context of climate change. According to Dietz (2011b) the key message from Weitzman $(2007,2009)$ is that estimates of the economic impacts of a changing climate should result from analyses in which the link between climate sensitivity and the damage function is represented by fat tail distributions.

Specifically, Weitzman argued that the modelling of uncertainty by Stern assumed a 'triangular' probability distribution of temperature increases, which

${ }^{13}$ Despite the limitations in data and attribution of extreme weather events to climate change, scientific analyses such as IPCC (2012) have also focused on managing the risks of said events. 
underestimated the risks of climate change. Weitzman was pointing in his argument to the need to explore temperature distributions with fat tails and the need to reflect on what the science was telling us could happen in terms of temperature rises for a doubling of $\mathrm{CO}_{2}$. According to Dietz (2011b) a log logistic distribution that allows temperature increases to range between $1.4^{\circ} \mathrm{C}$ and $14^{\circ} \mathrm{C}$ for a doubling of $\mathrm{CO}_{2}$ is a better fit for the data provided by AR4 and Weitzman (2009), compared to Stern's analysis which assumed a temperature range between $1.5^{\circ} \mathrm{C}$ and $4.5^{\circ} \mathrm{C}$. In fact, taking into account these fat tails to better reflect scientific data regarding climate sensitivity implies that the marginal damages of emissions and hence the benefits of reducing these emissions rise significantly. Weitzman argues that prompt and deep emission cuts advocated by the Stern team might be advisable, not as a consumption smoothing strategy but as an insurance premium paid that may help avoid 'ruinous catastrophe that is difficult to compensate by ordinary savings' (Weitzman, 2007: 703).

The early discounting debate has not been set aside but the consequences of having fat tailed probability distributions of temperature increases, and potentially catastrophic damages stemming from these, has arguably taken the centre stage in the current debate (Dietz, 2011b). The future research agenda in this area is likely to include severe tail events more prominently in an effort to reduce the deep uncertainty surrounding climate sensitivity and associated damages.

\section{THE GOVERNANCE OF CLIMATE CHANGE ${ }^{14}$}

'Regulation can be seen as being inherently about the control of risks' (Baldwin et al., 2012: 83). Regulation can also be understood as steering, controlling or influencing (Ogus, 2004). When regulation is dispersed to decision levels other than national governments, to institutions that include private firms, international institutions or NGO's, and when policy instruments include not only traditional command and control, but extend to economic instruments, allocation of property rights, voluntary agreements and moral suasion, we can speak of governance, even if no agreed definition exists yet in the literature (Jordan et al., 2005).

The first questions about the earth's energy balance were not asked until Joseph Fourier's work on the matter emerged in the 1820's. More than a century had to go by for the first signs of scientific cooperation on climate change to materialise. It was furthermore, not until the 1990's that political cooperation at the Rio summit (1992) gave birth to the United Nations Framework Convention on Climate Change. Despite the long road travelled to Kyoto and the 19 Conference of the Parties (COPs) that have followed since, actions to curb GHG in

${ }^{14}$ An extended version of this section will be published in Lázaro Touza, L. and Zoghby, M. (forthcoming). 
order to prevent dangerous interference with the climate system are insufficient, both at an international level and in terms of national actions. This section will succinctly review basic issues regarding the governance of climate change at an international level, mainly focusing on international climate negotiations following the Bali Action Plan.

\subsection{Negotiations and shared vision}

A priori, a world used to unilateral (national) management of environmental resources will underprovide a stable climate that requires joint management of public goods (Swanson and Johnston, 1999). In order to provide a stable climate, we need to move from unilateral decision-making, whereby countries have little incentives to reduce GHGs, to joint decision-making among sovereign countries. Said joint management of a stable climate can be articulated through IEAs. Mitchell (2003: 429) defines IEAs as 'legally binding intergovernmental efforts directed at reducing human impacts on the environment'.

In order for IEAs to be successful, participation needs to be broad (inclusion of main emitters ${ }^{15}$ is paramount), parties to the agreement must comply with their voluntarily undertaken commitments and the behaviour of emitters needs to substantially change, i.e. significant action to reduce GHGs needs to happen (Barrett, 2009). However, net benefits of joint mitigation are not always clear from the perspective of short term political cycles, equity issues have not been resolved, scientific certainty is still work in progress and no close substitutes exist for GHGs produced by virtually all human activities. In sum, the current prospects for jointly achieving a stable climate in time to limit temperature increases to $2^{\circ} \mathrm{C}$ compared to pre-industrial levels appear slim.

The existing barriers to a successful agreement have not however halted international negotiation efforts. The key international institutions ${ }^{16}$ established in the 1990's by the international community to fight climate change are: the UNFCCC and the $\mathrm{KP}^{17}$. Table 7 presents the key milestones in the international climate negotiation scene since the late 1980's.

\footnotetext{
${ }^{15}$ Please note that main emitters refer to China, the US, the EU, India, Japan and Russia (Marín González, 2011).

${ }^{16}$ Institution in this context is defined as "the prescriptions that humans use to organize all forms of repetitive and structured interactions including those within families, neighborhoods, markets, firms, sports leagues, churches, private associations and governments at all scales' (Ostrom, 2005: 3).

${ }^{17}$ Other key institutions where climate negotiations and actions are taking place at an international level include: the GEF, WTO, G8, MEF, IMO, ICAO, OECD, among other.
} 
Table 7

Key milestones in climate change negotiations

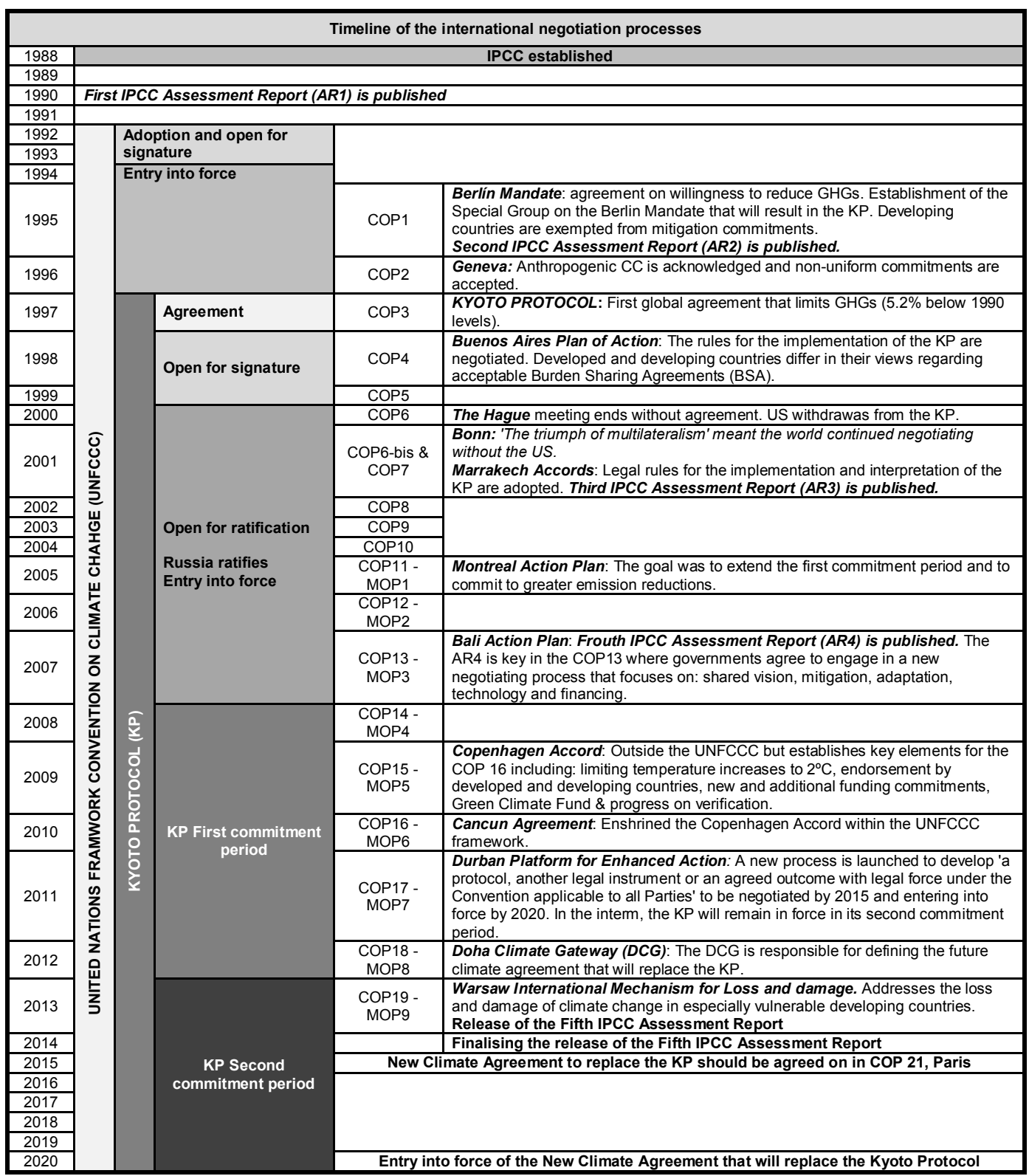

Source: Lázaro Touza and Zoghby (forthcoming).

Over two decades of international climate negotiations and assessment of existing peer reviewed scientific literature by the IPCC have helped develop a 
top-down negotiation framework that could provide the institutional space for effective climate action. The efforts made so far have to be evaluated against the goals the world strives to achieve in terms of limiting global average temperature increases. The following subsection will tell us that we have, so far, failed in this endeavour.

\subsection{Mitigation}

Mitigation can be loosely defined as the array of actions that reduce human influence on the climate system. These actions include reducing the amount of GHGs released or enhancing the absorption capacity of sinks such as forests and oceans ${ }^{18}$. The opening statement of the World Energy Outlook's (WEO) special report on climate and energy states that 'there is a growing disconnect between the trajectory that the world is on and one that is consistent with a $2^{\circ} \mathrm{C}$ climate goal' (IEA, 2013: 12). Similar statements have been issued by UNEP (2013), asserting that current mitigation commitments will only take us less than half way towards what is needed to stay within the $2^{\circ} \mathrm{C}$ mark.

Key sectors in which further mitigation is suggested are related either to energy use or to GHG absorption capacities (UNEP, 2013). The building sector for example could aid mitigation initiatives with the expansion of building codes, the use of appliance standards or the development of energy efficiency finance initiatives such as the PACE model (Van Nostrand, 2011). The transport sector could also apply more stringent fuel standards and public transport could be improved in many countries. Companies could increase home office working arrangements (Lázaro-Touza and López-Gunn, 2012). Another promising area in which GHG emission reductions are possible is the forestry sector. Increasing the protection of certain areas, while allowing indigenous communities to benefit from ecosystem services ${ }^{19}$, could help reduce GHG emissions from this sector.

How could the above-mentioned mitigation actions be included in the future climate architecture? One promising approach would be to increase the legal status of lower echelons of government in international climate negotiations (Ostrom, 2010; Moncel, 2012). Cities for example produce between two thirds and three fourths of GHG emissions. Yet, city representation has been limited at the global level until COP 16 (Von Lehe, 2011). Difficulties in this polycentric approach to climate governance are expected, as it is countries, and not cities, that are the subjects of international law. Despite the difficulties, the need to engage actors at all levels might help international climate negotiators provide

18 Please refer to http://www.ipcc.ch/publications_and_data/ar4/wg2/en/annexessglossary-eo.html for a complete glossary of climate terms used by the IPCC.

19 Ecosystem services are the benefits derived from ecosystems by humans. See: http://www.iucn.org/about/union/commissions/cem/cem_work/cem_services/ 
creative (and increasingly inclusive) solutions in future international climate negotiations.

\subsection{Adaptation}

No matter how successful mitigation efforts are in reducing GHGs, and whether the impacts of climate change materialise in the short or in the long term, natural and human systems will have to adapt. Some climate risks will be limited to sectors or regions, while others will have a domino effect. Below are some of these risks and potential for adaptation according to AR5.

Table 8

Risks and adaptation potential

\begin{tabular}{|c|c|c|}
\hline Observations & Risks & Adaptation potential \\
\hline $\begin{array}{l}\text { Freshwater } \\
\text { Resources }\end{array}$ & $\begin{array}{l}\text { Throughout the century, as warming in- } \\
\text { creases, people will increasingly be affected } \\
\text { by water scarcity and river floods }\end{array}$ & $\begin{array}{l}\text { Adaptive water management techniques } \\
\text { are expected to provide some resilience in } \\
\text { dealing with these risks }\end{array}$ \\
\hline $\begin{array}{l}\text { Terrestrial and } \\
\text { freshwater } \\
\text { ecosystems }\end{array}$ & $\begin{array}{l}\text { Depending on the level of warming, a 'large } \\
\text { fraction of both terrestrial and freshwater } \\
\text { species faces increased extinction risk' (IPCC, } \\
\text { 2014a: 15) }\end{array}$ & $\begin{array}{l}\text { While some management actions can } \\
\text { diminish the impacts of climate change on } \\
\text { these species, they will not completely } \\
\text { eliminate them }\end{array}$ \\
\hline $\begin{array}{l}\text { Coastal } \\
\text { systems and } \\
\text { low-lying areas }\end{array}$ & $\begin{array}{l}\text { As sea level rises throughout the century, } \\
\text { these systems will experience increased } \\
\text { adverse impacts, affecting both populations } \\
\text { and assets }\end{array}$ & $\begin{array}{l}\text { The costs of coastal adaptation will vary } \\
\text { significantly among regions, with some low } \\
\text { lying states incurring damage and adapta- } \\
\text { tion costs reaching 'several percentage } \\
\text { points of GDP' (IPCC, 2014a: 16) }\end{array}$ \\
\hline Marine systems & $\begin{array}{l}\text { By } 2050 \text {, ecosystem services such as } \\
\text { fisheries will be affected by a reduction in } \\
\text { biodiversity and the redistribution of species, } \\
\text { leading to a global fall in open-ocean produc- } \\
\text { tion by } 2100\end{array}$ & $\begin{array}{l}\text { For high technology industries forecasting } \\
\text { and early warning systems can mitigate } \\
\text { risk, while 'building social resilience' and } \\
\text { preparing for 'alternative livelihoods' } \\
\text { (IPCC, 2014d: 22) can minimize vulnera- } \\
\text { bility of populations in developing nations }\end{array}$ \\
\hline $\begin{array}{l}\text { Food security } \\
\text { and food } \\
\text { production } \\
\text { systems }\end{array}$ & $\begin{array}{l}\text { With or without adaptation, projected yield for } \\
\text { wheat, rice, and maize are expected to fall } 0 \\
\text { to } 2 \% \text { per decade this century, while demand } \\
\text { for these same crops is expected to rise by } \\
14 \% \text { per decade to } 2050\end{array}$ & $\begin{array}{l}\text { Overall, adaptation increases yields by } \\
\sim 15-18 \% \text {, but success is highly variable }\end{array}$ \\
\hline $\begin{array}{l}\text { Urban and rural } \\
\text { areas }\end{array}$ & $\begin{array}{l}\text { Urban areas are some of the most vulnerable } \\
\text { to the impacts of climate change such as } \\
\text { extreme weather events; while generally less } \\
\text { at risk, rural areas will also experience climate } \\
\text { related impacts through, for example, water } \\
\text { scarcity and diminishing agricultural revenues }\end{array}$ & $\begin{array}{l}\text { Adaptation in urban environments can be } \\
\text { accelerated by building resilience and } \\
\text { promoting sustainable development; the } \\
\text { resilience of vulnerable communities in } \\
\text { rural areas can be enhanced through, for } \\
\text { example, minimizing volatility in key } \\
\text { markets as well as investing in small scale } \\
\text { farming }\end{array}$ \\
\hline $\begin{array}{l}\text { Key economic } \\
\text { sectors and } \\
\text { services }^{20}\end{array}$ & $\begin{array}{l}\text { The economic impact of climate change is } \\
\text { difficult to estimate. It has been proposed that } \\
\text { for each } \sim 2^{\circ} \mathrm{C} \text { increase in temperature, eco- } \\
\text { nomic losses could range from } 0.2 \text { to } 2.0 \% \text { of } \\
\text { income, with the impact of each tonne of } \mathrm{CO}_{2} \\
\text { lying 'between a few dollars and several } \\
\text { hundreds of dollars' (IPCC, 2014a: 19) }\end{array}$ & $\begin{array}{l}\text { 'Large-scale public-private risk reduction } \\
\text { initiatives and economic diversification' are } \\
\text { examples of possible adaptation actions } \\
\text { (IPCC, 2014a: 19) }\end{array}$ \\
\hline
\end{tabular}

${ }^{20}$ See section 4 for further details. 
Table 8 (continue)

Risks and adaptation potential

\begin{tabular}{|l|l|l|}
\hline Observations & \multicolumn{1}{|c|}{ Risks } & \multicolumn{1}{|c|}{ Adaptation potential } \\
\hline Human health & $\begin{array}{l}\text { Prior to 2050, climate change is expected to } \\
\text { exacerbate already existing health issues, } \\
\text { while causing additional health problems } \\
\text { beyond 2050 }\end{array}$ & $\begin{array}{l}\text { Adaptation measures for health include } \\
\text { raising the level of basic public services } \\
\text { and focusing on poverty alleviation }\end{array}$ \\
\hline Human security & $\begin{array}{l}\text { Throughout the 21st century, climate change } \\
\text { will increasingly shape national security } \\
\text { policies and lead to new challenges to states, } \\
\text { such as increases in the displacement of } \\
\text { people and indirect increased risks of conflict }\end{array}$ & $\begin{array}{l}\text { A range of policy options will be required } \\
\text { to tackle these security issues }\end{array}$ \\
\hline $\begin{array}{l}\text { Livelihoods and } \\
\text { poverty }\end{array}$ & $\begin{array}{l}\text { Poverty in developing countries is expected to } \\
\text { be aggravated by the effects of climate } \\
\text { change, and create new 'pockets of poverty' } \\
\text { (IPCC, 2014a: 21) }\end{array}$ & $\begin{array}{l}\text { Adaptation measures will have to address } \\
\text { underlying poverty and inequality issues if } \\
\text { they are to be impactful }\end{array}$ \\
\hline
\end{tabular}

Source: (IPCC, 2014a,d).

As with mitigation, the main institutional settings for international adaptation negotiations and financing are the UNFCCC and the KP. However, while mitigation has been central to the Convention since its inception, it could be argued that adaptation to global climate change only began to be perceived as an equal complement to mitigation after the IPCC's Third Assessment Report (TAR). The challenge today for policy-makers and stakeholders is to translate the political momentum in support of adaptation into operational success (Garnaud, 2008).

Four major questions at the heart of any strategic approach to adaptation should be considered: Where to adapt, When to adapt, How to adapt, and Who should adapt? (Fankhauser and Soare, 2012). Answering these questions is especially challenging for developing countries as they are the most vulnerable and the least prepared to deal with climate change induced impacts and risks. The recognition that providing these populations with better protection against loss and damage caused by climate change lead to the establishment at COP19 (November 2013) of the Warsaw International Mechanism for Loss and Damage associated with climate change impacts. The mechanism is expected to become the Convention's primary vehicle through which loss and damage will be addresses in a comprehensive fashion.

\subsection{Technology transfer}

'To a large extent, the state of the environment today is the result of the technological choices of yesterday. Similarly, the state of the environment in the 21st century will be determined largely by the technologies we choose today' (Trindade, 2000: 29). Therefore, a broad range of technologies, particularly 
environmentally sound technologies (ESTs)21, will have to be deployed if human beings are to limit temperature increases to $2^{\circ} \mathrm{C}$ compared to pre-industrial levels.

However, countries clearly do not have the same capacities to address climate change. Generally speaking, developed nations have the means to meet the challenges of climate change, while many, if not most, developing nations lack the capacities to act effectively. Additionally the majority of technology transfers 22 occur within the countries that generate them. That being said, there has been growing momentum, through intellectual property legislation, multilateral organizations as well as private sector entities, for greater technology transfer (IPCC, 2000b).

In line with this trend, the Technology Transfer Framework was agreed during COP 7 (2001) under the Marrakesh Accords, followed by a Technology Mechanism at COP 16 in 2010. In addition, the market-based Clean Development Mechanism (CDM), established by the Kyoto Protocol, while not having an explicit technology transfer mandate, has contributed to the sustainable development of developing countries by supporting the transfer of technologies to projects aimed at reducing emissions (UNFCCC, 2010). Finally, the Global Environmental facility (GEF), an important multilateral body established in 1991 responsible for technology transfer, has been the largest source of public finance for ESTs (GEF, 2009) and is mandated by the UNFCCC to finance their transfer in the context of both mitigation and adaptation.

While multilateral organizations and governments can act as catalysts in support of technology transfer, it is predominantly private companies that are the producers and owners of ESTs. It is therefore relevant to identify the private sector pathways that can facilitate technology transfer. These pathways may involve international trade in hard and soft technologies through foreign direct investment (FDI), license or royalty agreements, turnkey projects, joint ventures, technical agreements, or other forms of cooperation arrangements.

A persistent hurdle on the path to technology transfer, and a hotly debated issue involving all stakeholders, is the issue of intellectual property rights (IPRs). The debate has mostly been framed in a developed vs. developing nations context. A range of measures and options have been advanced to further

${ }^{21}$ Environmentally Sound Technologies (ESTs): 'technologies that protect the environment are less polluting, use all resources in a more sustainable manner, recycle more of their wastes and products, and handle residual wastes in a more acceptable manner than the technologies for which they were substitutes' (IPCC, 2001: 372).

${ }^{22}$ Technology transfer in the context of climate change is defined by the Global Environment Facility as 'A broad set of processes covering the flows of know-how, experience and equipment for mitigating and adapting to climate change amongst different stakeholders' (GEF, 2012: 3). 
the issue, including the "expanded use of flexibilities in international intellectual property instruments; the exclusion of climate change technologies from patentability; and the consideration of arrangements such as patent pools to facilitate access to these technologies' (Latif, 2011: 3). However, it has been argued that the UNFCCC is not the appropriate forum to negotiate these issues, which are considered by many to be better addressed at the World Intellectual Property Organization (WIPO) or under the TRIPS Agreement (Rimmer, 2011; Latif, 2011). The COP19 climate talks in Warsaw resulted in no significant advance in either IPRs or ESTs (Tbach, 2013).

\subsection{Financing}

'Climate finance refers to local, national or transnational financing, which may be drawn from public, private and alternative sources of financing. Climate finance is critical to addressing climate change because large-scale investments are required to significantly reduce emissions, notably in sectors that emit large quantities of greenhouse gases. Climate finance is equally important for adaptation, for which significant financial resources will be similarly required to allow countries to adapt to the adverse effects and reduce the impacts of climate change' (https://unfccc.int/focus/finance/items/7001.php\#intro).

Developed nations party to the UNFCCC agreed in the 2009 Copenhagen Accord to provide new financing approaching USD 30 billion for the period 2010-2012 to be allocated in a balanced way between adaptation and mitigation (fast-start finance). They also agreed to commit to the goal of jointly mobilizing from multilateral, bilateral, public and private sources USD 100 billion a year by 2020 to address the needs of developing countries. Furthermore parties to the Convention agreed to establish a Green Climate Fund in support of developing countries' mitigation and adaptation efforts (UNFCCC, 2009).

Following the Copenhagen Accord, the Secretary General of the United Nations established in 2010 a High-level Advisory Group on Climate Change Financing. The Advisory group was tasked to report on the various sources of revenue susceptible to contribute to meeting the USD 100 billion a year by 2020 goal. The conclusion of the Advisory Group was that while meeting the US $\$ 100$ billion per year by 2020 goal would be challenging, it was feasible (UN, 2010).

As of the end of 2012, developed countries self-reported the delivery of more than $\$ 33$ billion in fast-start finance for the period 2010-2012 (WRI, 2012). However, reporting and accounting issues make it difficult to say how much funding has been disbursed or where it is going. Since 1998, OECD's Development Assistance Committee (DAC) has monitored climate change related aid through its 'Creditor Reporting System' (CRS). Data for 2011 show that total bilateral climate change-related aid by DAC's OECD members was USD 17.1 billion in 2011. Multilateral climate change-related aid was USD 894 
million in 2011 (OECD, 2013). Disappointingly, these numbers reflect a nearly 6 billion decline in climate change-related aid in 2011 compared to 2010 (OECD, 2012). While data for two consecutive years cannot be interpreted as a trend, the overall numbers seem to suggest that the world is far from being on track to meet its USD 100 billion a year by 2020 goal.

\section{CONCLUSIONS}

The present article has analysed climate change as a three pronged issue: scientific, economic and political. Recent scientific findings are clear on the threat posed by climate change as well as on its anthropogenic causes, despite uncertainty remaining on the magnitude and timing of impacts. Yet, the opening statement of the World Energy Outlook's (WEO) special report on climate and energy states that 'there is a growing disconnect between the trajectory that the world is on and one that is consistent with a $2^{\circ} \mathrm{C}$ climate goal' (IEA, 2013: 12).

We have also seen that economic analysis has been stretched beyond the marginal realm and beyond markets' lifetime when faced with analysing climate change. Economic models do not account for the entire range of impacts emerging from climate change. This limitation, in addition to ethical and technical debates on discounting, were the focus of early discrepancies in policy recommendations emerging from climate economics. Recent consideration of severe tail events has taken centre stage. The discounting sparring match is not over just yet but analysis of severe tail events has arguably shifted the focus of the debate and facilitated some agreement over the severity of climate change and the need for early action. Addressing climate change is likely to require that a price signal emerge globally. Climate change, the Goliath of externalities, should be internalised.

If the science of climate change is convincing in its recent calls for action, the international governance aspect of climate action is arguably disappointing. Mitigation commitments are insufficient to ensure we limit global average temperature increases to $2^{\circ} \mathrm{C}$ compared to pre-industrial levels. Adaptation is still the Cinderella of the party, despite recent initiatives at national and international levels. Financing is insufficient to meet 2020 commitments and the transfer of technology to those who need it most is likely to continue to be hindered by intellectual property rights issues, among others.

In order for IEAs to be successful, participation, compliance and behavioural change are of essence. That said, net benefits of mitigation are not always clear from a short-term perspective, equity issues have not been resolved, scientific uncertainty looms large and no close substitutes exist for GHGs. In sum, the current prospects for jointly achieving a stable climate in time to limit temperature increases to $2^{\circ} \mathrm{C}$ compared to pre-industrial levels appear slim. 


\section{REFERENCES}

BALDWIN, R., CAVE, M., and LODGE M. (2012): Understanding Regulation: Theory, Strategy and Practice, New York: Oxford University Press.

BARRETT, S. (2009): 'Rethinking Gobal Climate Change Governance' in Economics: The Open-Access, Open-Assessment E-Journal: 2009-5, pp. (1-12).

BLODGETT, J. and PARKER, L. (2010): Greenhouse Gas Emission Drivers: Population, Economic Development and Growth, and Energy Use. CRS Report for Congress.

DELL, M., JONES, B. F. and OLKEN, B. A. (2011): 'Temperature Shocks and Economic Growth: Evidence from the Last Half Century' in MIT, pp. (1-41).

DEPARTMENT of DEFENSE (DoD, 2010): Quadrennial Defense Review Report. February 2010. Department of Defense.

DIETZ, S. (2011a): 'From efficiency to justice: utility as the informational basis of climate strategies, and some alternatives' in DRYSEK, J. S, NORGAARD, R. H. and D. SCHOLSBERG (Eds.) The Oxford Handbook of Climate Change and Society pp. (295-308). Oxford: Oxford University Press.

DIETZ, S. (2011b): 'High impact, low probability? An empirical analysis of risk in the economics of climate change'. Climatic Change: 108, pp. (519-541).

DIETZ, S., HEPBURN, C. and Stern, N. (2008): 'Economics, ethics and climate change' in BASU, K. and KANBUR, R. (ed.) Arguments for a Better World: Essays in Honour of Amartya Sen Volume 2: Society, Institutions and Development): 2, pp. (365-386). Oxford: Oxford University Press.

DIETZ, S., STERN, N. and ZENGHELIS, D. (2007): 'Reflections on the Stern review (1). A Robust Case for Strong Action to Reduce the Risks of Climate Change'. World Economics: 8(1), pp. (121-168).

EBI, L. et al. (2013): 'A New Framework for Climate Change Research: Background, Process, and Future Directions'. Climatic Change: 122, pp. (363-372).

FANKHAUSER, S. \& SOARE, R. (2012): Strategic Adaptation to Climate Change in Europe. VividEconomics report prepared for the European Investment Bank. London.

GARNAUT, R. (2008): The Garnaut Climate Change Review. Melbourne: Cambridge University Press.

GLOBAL ENVIRONMENTAL FACILITY (GEF) (2012): Implementing the Poznan Strategic and Long-Term Programs on Technology Transfer.

GEF (2009): Technology Transfer for Climate Change.

HOPE, C. (2006): Calculating the Social Cost of Carbon. Available at: https://www.repository.cam.ac.uk/bitstream/handle/1810/194738/0749\&EPRG0720.p df?sequence=1 (20-5-2014).

HOWES, M. (2005): Politics and the Environment: Risk and the Role of Government and Industry. London: Earthscan.

http://sedac.ipcc-data.org/ddc/ar5_scenario_process/index.html. (18-5-2014).

https://unfccc.int/focus/climate_finance/items/7001.php . (23-5-2014).

http://www.ipcc.ch/publications_and_data/ar4/wg3/en/ch1s1-2-2.html. (25-07-2014).

INTERGOVERNMENTAL PANEL ON CLIMATE CHANGE (IPCC) (2014a): 'Climate Change 2014: Impacts, Adaptation, and Vulnerability. Summary for Policymakers'. 
Available at: http://ipcc-wg2.gov/AR5/images/uploads/WG2AR5_SPM_FINAL.pdf. (25-5-2014).

IPCC (2014b): Climate Change 2014: 'Impacts, Adaptation, and Vulnerability. Chapter 10'. Available at: http://ipcc-wg2.gov/AR5/images/uploads/WGIIAR5-Chap10_FGDall.pdf. (22-5-2014).

IPCC (2014c): 'Climate Change 2014: The Physical Science Basis. Summary for Policymakers'. Available at: http://www.climatechange2013.org/images/report/ WG1AR5_SPM_FINAL.pdf. (21-5-2014)

IPCC (2014d): Climate Change 2014: 'Impacts, Adaptation, and Vulnerability. Technical Summary'. Available at: http://ipcc-wg2.gov/AR5/images/uploads/WGIIAR5-TS_FGDall.pdf. (13-5-2014).

IPCC (2014e): Climate Change 2014: Impacts, Adaptation, and Vulnerability. Chapter 21. Available at: http://ipcc-wg2.gov/AR5/images/uploads/WGIIAR5-Chap21_FGDall.pdf. (23-5-2014).

IPCC (2014f): Climate Change 2014: 'Impacts, Adaptation, and Vulnerability. Chapter 15'. Available at: http://ipcc-wg2.gov/AR5/images/uploads/WGIIAR5-Chap15_FGDall.pdf. (22-5-214).

IPCC (2012), Managing the Risks of Extreme Events and Disasters to Advance Climate Change Adaptation. Summary for Policy Makers. http://ipcc-wg2.gov/SREX/images/ uploads/SREX-SPMbrochure_FINAL.pdf (25-07-2014).

IPCC (2007a): Climate Change 2007: Synthesis Report. Available at: http://www.ipcc.ch/publications_and_data/ar4/syr/en/contents.html. (21-5-2014).

IPCC (2007b): Climate Change 2007: Impacts, Adaptation and Vulnerability. Chapter 20. Available at: http://www.ipcc.ch/pdf/assessment-report/ar4/wg2/ar4-wg2-chapter20.pdf. (29-5-2014)

IPCC (2007c): Climate Change 2007: The Physical Science Basis. Chapter 2. http://www.ipcc.ch/pdf/assessment-report/ar4/wg1/ar4-wg1-chapter2.pdf. (22-5-2914).

IPCC (2007d): Further Work on Scenarios Report from the IPCC Expert Meeting Towards New Scenarios for Analysis of Emissions, Climate Change, Impacts, and Response Strategies. http://www.ipcc.ch/pdf/supporting-material/expert-meeting-tsscenarios.pdf. (23-5-2014).

IPCC (2001b): Glossary, IPCC Third Assessment Report - Climate Change 2001. The Scientific Basis. http://www.ipcc.ch/ipccreports/tar/wg1/index.php?idp=518. (24-52014).

IPCC (2000a): Special Report - Emissions Scenarios. Summary for Policymakers. Available at: http://www.ipcc.ch/pdf/special-reports/spm/sres-en.pdf. (10-5-2014)

IPCC (2000b): Methodological and technological issues in technology transfer. A special report of the International Panel on Climate Change (IPCC) Working Group III.Available at: https://www.ipcc.ch/pdf/special-reports/spm/srtt-en.pdf. (10-5-2014).

INTERNATIONAL ENERGY AGENCY (IEA) (2013): Redrawing the Energy-Climate Map. World Energy Outlook Special Report.

JORDAN, A. et al. (2010): Climate Change Policy in the European Union. Confronting the Dilemmas of Mitigation and Adaptation, Cambridge: Cambridge University Press.

JUBB, I., CANADELL P., DIX, M. (Undated): Representative Concentration Pathways. Australian Climate Change Science Program. Information Letter. DOE - Australian Government. 
KRIEGLER, E. et al. (2014): 'A New Scenario Framework for Climate Change Research: the Concept of Shared Climate Policy Assumptions'. Climatic Change. 122: 401-414.

LATIF, A. A. et al. (2011): Overcoming the Impasse on Intellectual Property and Climate Change at the UNFCCC: A Way Forward. ICTSD Programme on Innovation, Technology and Intellectual Property. Policy Brief $n^{\circ}$. 11. November 2011.

LÁZARO TOUZA, L. and ZOGHBY, M. (forthcoming): 'Climate risks: theory, data and the global governance of climate change' in FERREIRA RODRIGUES , T., GARCÍA PÉREZ, R. and de SOUSA FERREIRA, S. (ed.) Globalization and Security Issues. Nova Science Publishers.

LÁZARO TOUZA, L. and LÓPEZ-GUNN, E. (2012): Climate Change Policies - Mitigation and Adaptation at the Local Level: The Case of the City of Madrid (Spain) in Tortora, M. (ed.), Sustainable systems and energy management at the regional level: comparative approaches, pp. (261-287). Hershey: IGI Global.

LENTON, T. M., HELD, H. et al. (2008): 'Tipping elements in the Earth's climate system'. Proceedings of the National Academy of Sciences. 105(6): pp. (1786-1793).

LIM, B. et al. (Eds.) (2004): Adaptation Policy Frameworks for Climate Change: Developing Strategies, Policies and Measures. Cambridge: United Nations Development Program.

LUDERER, G., BOSETTI, V., JAKOB, M., LEIMBACH, M., STECKEL, J. C., WAISMAN, $\mathrm{H}$. and EDENHOFER, O. (2012): 'The economics of decarbonizing the energy system-results and insights from the RECIPE model intercomparison'. Climatic Change.114: pp. (9-37).

MARÍN GONZÁLEZ, M. (2011): 'Seguridad, Modelo Energético y Cambio Climático' in Ministerio de Defensa (Ed.), Seguridad, Modelo Energético y Cambio Climático. Cuadernos de Estrategia. Cuadernos de Estrategia, 150: pp. (15-25). Madrid: Instituto Español de Estudios Estratégicos.

MENDELSOHN, R. O., MORRISON. W. N., SCHLESINGER, M. E. Schlesinger, and ANDRONOVA. N. G. (1998): 'Country-specific market impacts of climate change'. Climatic Change 45 (3-4): 553-569.

MITCHELL, R. B. (2003): 'International Environmental Agreements: A Survey of their Features, Formation, and Effects', Annual Review of Environmental Resources, 28: pp. (429-61).

MONCEL, R. (2012): 'Unconstructive Ambiguity in the Durban Climate Deal of COP17/CMP7'. Sustainable Development Law and Policy, 2: pp. (6-11).

MULLAN, M., KINGSMILL, N. KRAMER, A.M. and AGRAWALA, S. (2013): National Adaptation Planning: Lessons from OECD Countries, OECD Environment Working Papers, No. 54, OECD Publishing.

NATIONAL RESEARCH COUNCIL (2013): Abrupt Impacts of Climate Change: Anticipating Surprises. Washington DC: The National Academies Press.

NORDHAUS, W. (2013): The Climate Casino. Risk, Uncertainty and Economics for a Warming World. New Haven: Yale University Press.

NORDHAUS, W. (2012): 'Economic Policy in the Face of Severe Tail Events'. Journal of Public Economic Theory, 14(2): pp. (197-219).

NORDHAUS, W. (2007): 'A Review of the Stern review on the Economics of Climate Change'. Journal of Economic Literature, XLV: pp. (686-702).

Organisation for Economic Co-operation and Development (OECD) (2013): OECD DAC Statistics on Climate-Related Aid. 
OECD (2012): OECD DAC Statistics on Climate-Related Aid.

OGUS, A. I. (2004): Regulation: Legal Form and Economic Theory. Oxford: Hart Publishing.

OSTROM, E. (2010): 'Polycentric systems for coping with collective action and global environmental change'. Global Environmental Change, 20: pp. (550-557).

OSTROM, E. (2005): Understanding Institutional Diversity. Princeton: Princeton University Press.

RIMMER, M. (2011): Intellectual Property and Climate Change: Inventing Clean Technologies. Cheltenham: Edward Elgar Publishing.

ROGELJ, J., MEINSHAUSEN M., KNUTTI R. (2012): 'Global Warming Under Old and New Scenarios Using IPCC Climate Sensitivity Range Estimates'. Nature Climate Change Letters, 2: pp. (248-253).

SINGLEY, J. A. (2004): Hazard versus Risk. Chemical Health and Safety. Vol. 11(1): 1416.

STERN, N. (2013a): Ethics, Equity and the Economics of Climate change. Paper 1: Science and Philisophy. Grantham Research Institute on Climate Change and the Environment. Working Paper No. 84a.

STERN, N. (2013b): Ethics, Equity and the Economics of Climate change. Paper 2: Economics and Politics. Grantham Research Institute on Climate Change and the Environment. Working Paper No. 84b.

STERN, N. (2007): The Economics of Climate Change: the Stern Review. Cambridge: Cambridge University Press.

STERN, N. (2006): Stern Review on the Economics of Climate Change, $15^{\text {th }}$ of November 2006. Presentation to the Convention Dialogue, Nairobi.

SWANSON, T. and JOHNSTON, S. (1999): Global Environmental Problems and International Environmental Agreements. Cheltenham: Edward Elgar Publishing.

TBACH (2013): US-China relations post-COP19. Vermont School of Law.

TOL, R. (2012): 'The Uncertainty about the Total Economic Impact of Climate Change'. Environmental and Resource Economics, 53(1): pp. (97-116).

TRINDADE, S. C. (2000): Paper 2: A Flexible Framework for Meaningful and Effective Actions to Enhance the Implementation of Article 4.5 of the UNFCCC.

UNITED NATIONS (UN) (2013): World Population Prospects. The 2012 Revision. Volume I: Comprehensive tables. Department of Economic and Social Appairs. Population Division.

UN (2010): Report of the Secretary-General's High-level Advisory Group on Climate Change Financing.

UNITED NATIONS ENVIRONMENTAL PROGRAMME (UNEP) (2013): The Emissions Gap Report 2013. A UNEP synthesis Report.

UNITED NATIONS FRAMEWORK CONVENTION ON CLIMATE CHANGE (UNFCCC) (2010): The Contribution of the Clean Development Mechanism Under the Kyoto Protocol to Technology Transfer.

UNFCCC (2009): Copenhagen Accord. Decision CP.15.

VAN NOSTRAND, J. M. (2011): 'Legal Issues in Financing Energy Efficiency: Creative Solutions for Funding the Initial Capital Costs of Investments in Energy Efficiency Measures'. Journal of Ennergy and Environmental Law, Winter: pp. (1-16). 
VON LEHE, A. (2011): 'Cities, climate and COPs'. Southeastern Environmental Law Journal, 19: pp. (217-230).

WEITZMAN, M. (2011): The social cost of carbon. ESRI working paper, No. 377.

WEITZMAN, M. (2010): 'What is the 'damages function' for global warming and what difference does it make?' Climate Change Economics, Vol. 1(1): pp. (57-69).

WEITZMAN, M. (2009): 'On modeling and interpreting the economics of catastrophic climate change'. Review of Economics and Statistics, 91(1): pp. (1-19).

WEITZMAN, M. (2007): 'A Review on The Stern Review on the Economics of Climate Change'. Journal of Economic Literature, XLV: pp. (703-724).

World Resources Institute (WRI) (2012): Fast-Start Finance: Where Do We Stand at the End of 2012? WRIInsights. 